Please do not remove this page

RMIT

UNIVERSITY

\title{
Solution-processed CuSbS2 thin films and superstrate solar cells with CdS/In2S3 buffer layers
}

van Embden, Joel; De Sousa Mendes, Joao Otavio; Jasieniak, Jacek; Chesman, Anthony; Della Gaspera, Enrico

https://researchrepository.rmit.edu.au/esploro/outputs/9921905796501341/filesAndLinks?institution=61RMIT_INST\&index=null

Van Embden, J., De Sousa Mendes, J. O., Jasieniak, J., Chesman, A., \& Della Gaspera, E. (2020).

Solution-processed CuSbS2 thin films and superstrate solar cells with CdS/In2S3 buffer layers. ACS

Applied Energy Materials, 3(8), 7885-7895. https://doi.org/10.1021/acsaem.0c01296

Document Version: Accepted Manuscript

Published Version: https://doi.org/10.1021/acsaem.0c01296

Repository homepage: https://researchrepository.rmit.edu.au

(c) 2020 American Chemical Society

Downloaded On 2023/04/26 19:39:06 +1000 


\title{
Solution-Processed CuSbS2 Thin Films and Superstrate Solar Cells with $\mathrm{CdS} / \mathrm{In}_{2} \mathrm{~S}_{3}$ Buffer Layers
}

\author{
Joel van Embden $^{a^{*}}$, Joao O. Mendes ${ }^{a}$, Jacek J. Jasieniak ${ }^{b}$, Anthony S. R. Chesman ${ }^{c}$, Enrico Della \\ Gaspera $^{a}$ \\ a. School of Science, RMIT University, Victoria 3001, Australia.

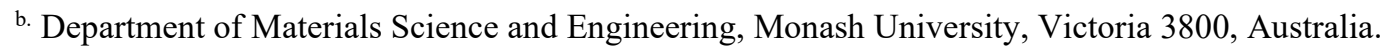 \\ c. CSIRO Manufacturing, Bayview Ave Clayton, Victoria 3168, Australia
}

KEYWORDS: copper, antimony, chalcogenide, solution processing, semiconductor, sulfide

\begin{abstract}
Herein we describe a method to deposit thin films of the semiconductor $\mathrm{CuSbS}_{2}$ with micrometer-sized grains under inert atmospheres at mild processing temperatures. This is achieved through the decomposition of $\mathrm{Cu}$ and $\mathrm{Sb}$ dithiocarbamate precursors. Through careful optimization of the processing conditions, phase-pure p-type $\mathrm{CuSbS}_{2}$ thin films with high photoconductivity have been achieved. Tunability of the $\mathrm{Cu}: \mathrm{Sb}$ ratios is also demonstrated while maintaining phase purity. Photoelectrochemistry is conducted as a function of both processing temperature and $\mathrm{Cu}: \mathrm{Sb}$ ratio with $10 \%$ copper deficient films annealed between $350^{\circ} \mathrm{C}$ and $400{ }^{\circ} \mathrm{C}$ producing the highest relative photocurrent. Finally, to assess the performance of these thin films, planar thin film solar cells are fabricated. Superstrate solar cells $\left(\mathrm{Glass} / \mathrm{FTO} / \mathrm{CdS} /\left(\operatorname{In}_{2} \mathrm{~S}_{3}\right) / \mathrm{CuSbS}_{2} / \mathrm{SPIRO} / \mathrm{Au}\right)$ with either a CdS n-type window layer or a CdS/In $\mathrm{S}_{3}$ dual n-type window/buffer layer are investigated. The use of a thin buffer layer further boosts the overall device performance and a champion power conversion efficiency of $1.72 \%$ is demonstrated. To date, this efficiency is among the best reported for $\mathrm{CuSbS}_{2}$ solar cells and the highest for solution-processed devices using a planar thin film architecture.
\end{abstract}

\section{INTRODUCTION}

The ability to fabricate high quality semiconductor thin films using solution-based (vacuum free) processing conditions has opened the door to low-cost thin film devices, including photodetectors $^{1-3}$, batteries $^{4}$, photocatalysts $^{5,6}$, and solar cells. ${ }^{7-}$ ${ }^{10}$. A range of solution processes exist to produce crystalline semiconductor thin films. The most common methods include chemical bath deposition (CBD) 11-15, electrochemical deposition ${ }^{16-18}$, successive ion layer adsorption and reaction (SILAR) ${ }^{19-21}$, nanocrystal (NC) assembly ${ }^{22-27}$, and molecular precursors (MP) ${ }^{28-32}$. Of these techniques, the use of molecular precursors provides perhaps the most versatile, reproducible, and facile approach to achieving semiconductor thin films across a wide range of materials.

At present, a multitude of investigations into the fabrication of metal chalcogenide thin films from MPs have been reported 9,33-40. These reports focused largely on the generation of thin films for use in photodetectors and photovoltaic (PV) devices. In efforts to extend these methods the exploration of metal chalcogenide (nano)materials developed to include copper antimony sulfide (CAS) semiconductors. Since the first synthesis of a CAS nanomaterial by the current authors ${ }^{41}$, investigations into this class of materials have continued to expand. Numerous investigations have been conducted into the dominant phases of CAS, namely, tetrahedrite $\left(\mathrm{Cu}_{12} \mathrm{Sb}_{4} \mathrm{~S}_{13}\right)^{42} 43-$ ${ }^{45}$, famatinite $\left(\mathrm{Cu}_{3} \mathrm{SbS}_{4}\right)^{41,46}$, and chalcostibite $\left(\mathrm{CuSbS}_{2}\right)^{47-50}$, as well as few reports on the synthesis and characterization of skinnerite $\left(\mathrm{Cu}_{3} \mathrm{SbS}_{3}\right){ }^{51},{ }^{52}$. All these phases are p-type semiconductors with high absorption coefficients $\left(\sim 10^{4}-10^{5}\right.$ $\mathrm{cm}^{-1}$ ), direct bulk band gaps that vary between $\sim 1-1.8 \mathrm{eV}$, modest hole mobilities between $10-70 \mathrm{~cm}^{2} / \mathrm{V} . \mathrm{s}{ }^{42,51,53,54}$, and good defect tolerances ${ }^{53,55}$. Collectively, these properties make them suitable candidates for vis-NIR photodetectors or solar absorber layers in PV devices.

In addition to having the appropriate optical and electrical properties, CAS (and antimony containing chalcogenides in general) have very low melting points, for example; $\mathrm{Sb}_{2} \mathrm{~S}_{3}(550$ $\left.{ }^{\circ} \mathrm{C}\right), \mathrm{Sb}_{2} \mathrm{Se}_{3}\left(611{ }^{\circ} \mathrm{C}\right), \mathrm{CuSbS}_{2}\left(551{ }^{\circ} \mathrm{C}\right)$, and $\mathrm{Cu}_{12} \mathrm{Sb}_{4} \mathrm{~S}_{13}(580$ $\left.{ }^{\circ} \mathrm{C}\right)$. This property has previously been exploited to enhance the grain growth of CIGS thin films though the generation of antimony chalcogenide "flux agents" ${ }^{56}$. Such low melting temperatures enable CAS to form microcrystalline thin films desirable for PV application under mild conditions, without the need for vacuum-based infrastructure or post-processing sulfurization/selenization steps. This provides a unique processing advantage over more established metal chalcogenide semiconductors.

In view of their well-suited optical properties, chemical stability, and processing advantages, recent research has focused on the implementation of CAS in solar cell devices. An 
in-depth outline of current CAS device performances can be found in excellent recent reviews ${ }^{57,58} . \mathrm{Cu}_{12} \mathrm{Sb}_{4} \mathrm{~S}_{13}{ }^{44}, \mathrm{Cu}_{3} \mathrm{SbS}_{4}{ }^{59}$, and $\mathrm{Cu}_{3} \mathrm{SbS}_{3}{ }^{60}$ solar cells have all been fabricated, however, these solar cells have all suffered from very poor $(<<0.5 \%)$ efficiencies. The outlier within the CAS system is $\mathrm{CuSbS}_{2}$ (isostructural with $\mathrm{CuInS}_{2}$ ), with far more promising efficiencies emerging.

Vacuum-based solar cell fabrication methods for $\mathrm{CuSbS}_{2}$ include the high temperature sulfurization of electro-deposited metal stacks, metal salts, or nanoparticles, as well as the cosputtering and co-evaporation of the corresponding binary sulfides ${ }^{61-64}$. These solar cells are predominantly built on molybdenum substrates and have produced the best efficiencies to date. However, solution-based methods are still lagging behind. There remains significant impetus to further develop such methods as they have the ability to circumvent vacuumbased deposition and/or high temperature chalcogenization steps and make use of the aforementioned processing advantages afforded by the low melting point of $\mathrm{CuSbS}_{2}$. To date, the best performing $\mathrm{CuSbS}_{2}$ solution processed cells are based on nanostructured architectures, with sensitized $\mathrm{ZnO}$ nanorods $(n=1.61 \%)^{65}$ and mesoporous $\mathrm{TiO}_{2}(\mathrm{n}=3.1 \%){ }^{66}$ the current top performers.

Thin film (not sensitized) architectures are far more challenging. For planar thin film solar cells film quality is paramount, requiring careful optimization of the processing conditions, thin film morphology, and cell interfaces given that charge transport cannot be simply driven by the mesoporous or nanostructured scaffold material. Over the past few years numerous efforts have been put into developing high quality $\mathrm{CuSbS}_{2}$ thin films by solution processes. Such approaches to $\mathrm{CuSbS}_{2}$ thin films have included thiol-amine mixtures ${ }^{54}$, metal xanthates ${ }^{67}$, and thioglycolic acid-amine mixtures ${ }^{68}$. However, despite reporting their film quality, in each of these cases no $\mathrm{CuSbS}_{2}$ devices were fabricated from the resultant films. Notable exceptions include studies by Tang et al. who fabricated $\mathrm{CuSbS}_{2}$ thin films from hydrazine with efficiencies at $0.5 \%{ }^{53}$ and Dai et al. who used MPs to reach $0.68 \%{ }^{69}$. Other approaches have also been employed, including $\mathrm{CBD}^{70}$ and spray-coating ${ }^{71}$ methods, but again only poor cell efficiencies (up to $0.66 \%$ ) were reported. To date, the record efficiency for solution processed thin film $\mathrm{CuSbS}_{2}$ solar cells remains below the benchmark of $1 \%$ for emergent devices.

Here we provide a comprehensive investigation into $\mathrm{CuSbS}_{2}$ thin films fabricated from dithiocarbamate (DTC) MPs. A method to fabricate high quality $\mathrm{CuSbS}_{2}$ thin films with large grain sizes (without the need for sulfurization) is presented. The structural, optical, and photo-electrochemical properties of these films are investigated. In depth studies into the effects of temperature and $\mathrm{Cu} / \mathrm{Sb}$ composition on the optical and optoelectronic properties of the thin films are presented with a view to generating optimal photoactive thin $\mathrm{CuSbS}_{2}$ films. Finally, superstrate $\mathrm{CuSbS}_{2}$ planar thin film solar cells are fabricated and analyzed. Record devices were fabricated using double n-type $\mathrm{CdS} / \mathrm{In}_{2} \mathrm{~S}_{3}$ "window" layers, which greatly improve the device characteristics over a single CdS buffer layer, breaking the $1 \%$ efficiency barrier in such devices for the first time.

\section{RESULTS AND DISCUSSION}

\section{$\mathrm{CuSbS}_{2}$ Thin Film Characterization}

The films were prepared as outlined in the Experimental section. X-ray Diffraction (XRD) was used to establish the phase purity of the as-deposited thin films. The film thicknesses of the samples were adjusted to $\sim 500 \mathrm{~nm}$, with a deviation in the film thickness of less than $10 \%$. Figure 1a shows multiple XRD patterns from films prepared with different stoichiometries ranging from copper poor $(\mathrm{Cu}: \mathrm{Sb} ; 0.8: 1)$ to copper rich (Cu:Sb; 1.2:1). All films display clear sharp peaks indicative of a highly crystalline material. Each of these peaks and their corresponding intensities match perfectly to orthorhombic chalcostibite $\mathrm{CuSbS}_{2}$ (ICDD\# 00-044-1417).
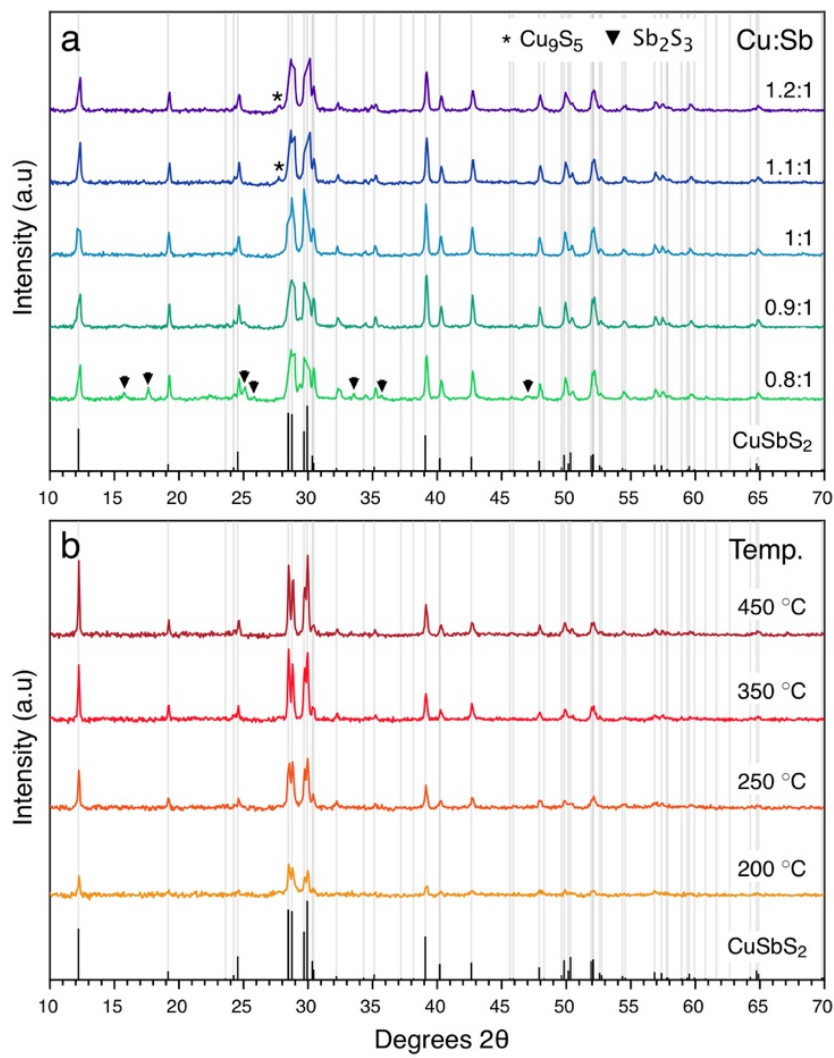

Figure 1: a) $\mathrm{XRD}$ patterns of $\mathrm{CuSbS}_{2}$ thin films annealed at 350 ${ }^{\circ} \mathrm{C}$ as a function of $\mathrm{Cu}: \mathrm{Sb}$ mole ratios in the precursor solutions. It can be seen that copper deficient precursor solutions $(\mathrm{Cu} / \mathrm{Sb}<0.9)$ lead to the formation of $\mathrm{Sb}_{2} \mathrm{~S}_{3}$ in addition to $\mathrm{CuSbS}_{2}$, while copperrich $(\mathrm{Cu} / \mathrm{Sb} \geq 1.1)$ solutions favor $\mathrm{Cu}_{9} \mathrm{~S}_{5}$ formation. $\left.b\right)$ The effect of annealing temperature on $\mathrm{CuSbS}_{2}$ thin films with $\mathrm{Cu}: \mathrm{Sb} ; 1: 1$.

It is well known that tuning the stoichiometry of ternary and quaternary semiconductors can have a dramatic effect on their optoelectronic properties ${ }^{72-75}$. With this in mind the copper/antimony mole ratio within the molecular precursor solutions was altered to evaluate phase purity of the resultant films as a function of composition. In the case of the most copper deficient films ( $\mathrm{Cu}: \mathrm{Sb}$; 0.8:1; light green trace) the precipitation of a secondary phase is seen to occur as indicated by the appearance of multiple additional peaks in the XRD pattern (triangle markers). Upon analysis each of these peaks may be indexed to $\mathrm{Sb}_{2} \mathrm{~S}_{3}$ (ICDD\# 00-042-1393). Conversely, for copper-rich films $(\mathrm{Cu}: \mathrm{Sb} ; 1.1: 1$; dark blue trace, and $\mathrm{Cu}: \mathrm{Sb}$; $1.2: 1$; purple trace) a small additional peak at $\sim 27.8^{\circ}$ may be observed, which can be indexed to $\mathrm{Cu}_{9} \mathrm{~S}_{5}$ (ICDD\#00-0471748). Slightly copper-poor films with $\mathrm{Cu}: \mathrm{Sb} ; 0.9: 1$ could be 
made without the formation of any secondary phases. From these results it is clear that the $\mathrm{CuSbS}_{2}$ lattice is slightly more tolerant to copper deficiencies compared to the accommodation of excess copper. One of the possible causes of this tolerance is the unusual stability of the defect pair $\left(2 \mathrm{~V}^{0} \mathrm{Cu}+\mathrm{In}^{0} \mathrm{Cu}\right) .{ }^{76}$ These findings are consistent with other copper containing semiconductors, such as $\mathrm{CuSnSe}_{3}, \mathrm{CuZnSnS}_{4}, \mathrm{CuInS}_{2}$ and $\mathrm{CuIn}_{\mathrm{x}} \mathrm{Ga}_{1-\mathrm{x}} \mathrm{Se}_{2} .{ }^{77}$

In the presence of large amounts of sulfur (from the excess dithiocarbamate ligands), the continued decrease in copper concentration facilitates the homogeneous nucleation of antimony sulfide. It should be noted that antimony sulfide was found to be the dominant impurity in $\mathrm{Cu}: \mathrm{Sb}(1: 1)$ mixtures if copper acetate was used instead of copper oxide in the synthesis of the dithiocarbamate precursor (see Supporting Information, Figure S1). This indicates that the speciation (counter anion) of the copper precursors also plays a significant role in the reactivity of the metal-DTC molecular precursor, its decomposition pathway and the subsequent phase purity of the film. ${ }^{78}$ Additional evidence of this phenomenon was gleaned from early trials using metal thiourea precursors. It was observed that the reactivities of the metal complexes with thiourea and with each other were vastly different depending on the counter anion used. Clear solutions (without precipitate) could only be achieved when using both $\mathrm{Cu}$ and $\mathrm{Sb}$ chlorides. In cases where viable thiourea-based precursors solutions were formed the resulting films were nonetheless of poor quality (for details see Supporting Information, Table S1). Overall, the observation that metal oxide-derived DTC molecular precursors provides phase pure high-quality films while tuning metal ratios is evidence that (unlike thiourea precursors) the reactivity of both the copper and antimony DTC species are well matched.

Figure $1 \mathrm{~b}$ shows the effect of annealing temperature on the XRD patterns of the $\mathrm{CuSbS}_{2}$ thin films (Cu:Sb; $\left.1: 1\right)$. All of the films were initially fabricated in air by spin coating multiple layers with an intermediate decomposition step at $200{ }^{\circ} \mathrm{C}$. The samples were then heated in an inert atmosphere (glove box) for $30 \mathrm{~min}$ at the designated temperature. Each film was approximately the same thickness $(600 \pm 34 \mathrm{~nm})$. As such, the observed changes in the intensity of the peaks in the XRD patterns are a direct consequence of changes in the annealing temperature alone.

Remarkably, quite sharp peaks are observed at temperatures as low as $200{ }^{\circ} \mathrm{C}$. The low-temperature crystallization of $\mathrm{CuSbS}_{2}$ may be primarily attributed to the highly reactive nature of the dithiocarbamate precursors ${ }^{36,79}$. Notably, systems employing metal-thiourea complexes do not show comparative crystallinity until $300{ }^{\circ} \mathrm{C}$ and are not claimed to be phase pure until $500^{\circ} \mathrm{C}$. However, in this case only questionable evidence exists that thiourea precursors are able to generate phase pure $\mathrm{CuSbS}_{2}$ without $\mathrm{Sb}_{2} \mathrm{~S}_{3}$ impurities ${ }^{66}$. With an increase in annealing temperature the samples became more crystalline, as indicated by an increase in the intensity of the diffraction peaks. No significant changes to the XRD patterns were observed for annealing temperatures above $300{ }^{\circ} \mathrm{C}$. The ability to achieve phase pure $\mathrm{CuSbS}_{2}$ at $200{ }^{\circ} \mathrm{C}$ is further testament to the balanced reactivity of both precursors at such low temperatures. A table including the crystallite size evaluated from the diffraction peaks is available in the Supporting Information as Table S2.

XPS was also performed on the stoichiometric $(\mathrm{Cu}: \mathrm{Sb}, 1: 1)$ films (see Supporting Information, Figure S2 for details).
Collectively, all the peaks matched with those of the elements in their expected oxidation states; $\mathrm{Sb}(\mathrm{III}), \mathrm{Cu}(\mathrm{I})$, and $\mathrm{S}(2-)$ and free from oxide peaks from contaminants and from $\mathrm{Cu}(\mathrm{II})$ inclusions, unlike observed in other CAS phases ${ }^{42}$.

It has been determined that the processing environment can have a dramatic effect on the crystal phase within the CAS system ${ }^{42}$. As such, we conducted investigations into the effect of processing environment on $\mathrm{CuSbS}_{2}$ films, with the objective of elucidating what conditions induce chemical changes in $\mathrm{CuSbS}_{2}$. Such an understanding is valuable given that even trace contaminant regions (undetectable using XRD) within $\mathrm{CuSbS}_{2}$ may act as recombination centers that may ultimately inhibit device performance. As such, experiments were performed to observe the long-time behavior of annealing $\mathrm{CuSbS}_{2}$ thin films in different chemical environments (see Supporting Information, Figure S3 and related text for details). Briefly, it was observed that heating $\mathrm{CuSbS}_{2}$ in an inert atmosphere of nitrogen at $500{ }^{\circ} \mathrm{C}$ for one hour has no effect on the phase, while heating even at a lower temperature of $400{ }^{\circ} \mathrm{C}$ in a sulfur-rich atmosphere induced a phase change to famatinite $\mathrm{CuSbS}_{4}$ and was accompanied by the loss of $\mathrm{Sb}_{2} \mathrm{~S}_{3}$. It may be concluded that (unlike its famatinite and tetrahedrite analogues) the presence of sulfur in the annealing atmosphere and not temperature is the requisite driving force behind phase changes in the $\mathrm{CuSbS}_{2}$ system, which provides confidence in the processing of these films in inert atmospheres.
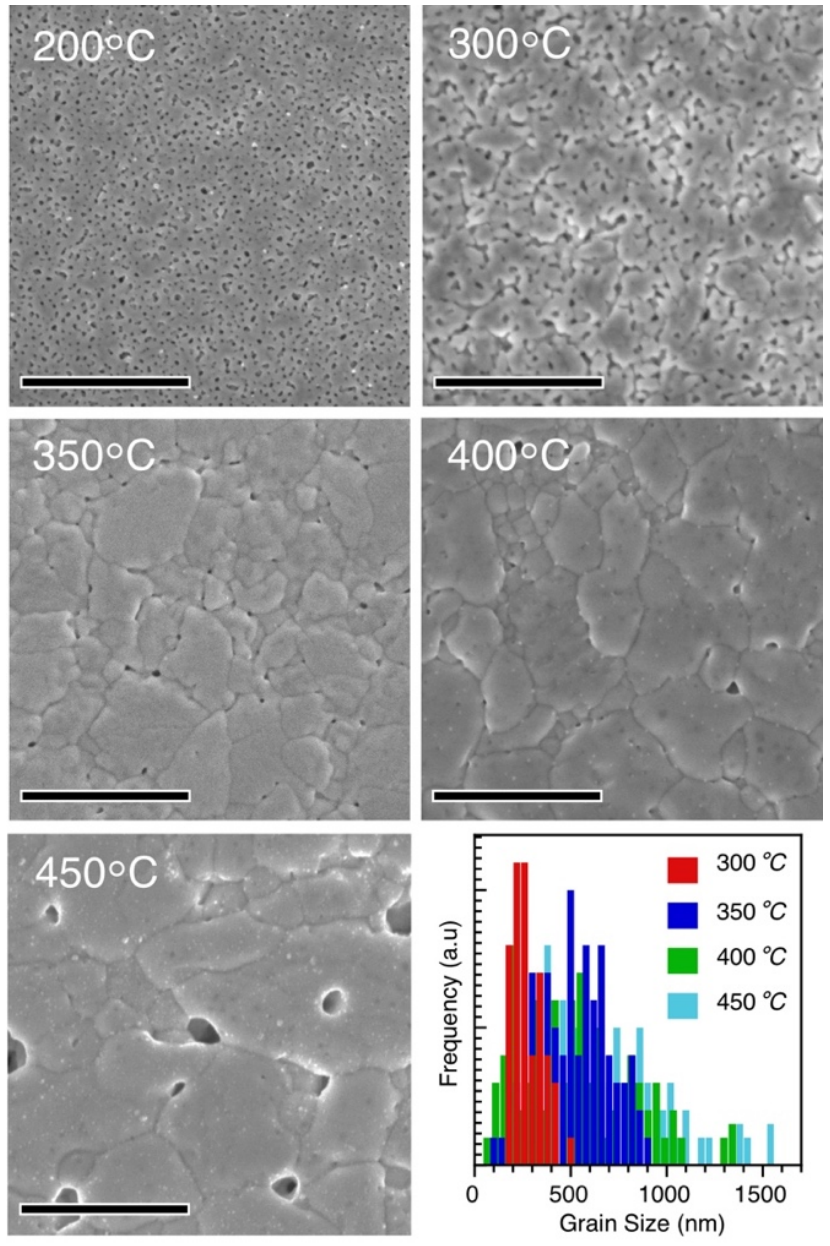

Figure 2: Top view SEM images of $\mathrm{CuSbS}_{2}$ thin films annealed at different temperatures in a glove box for $30 \mathrm{~min}$. Scale bars $1 \mu \mathrm{m}$. The bar chart shows the distribution of grain sizes $(>100$ individual 
grains) versus annealing temperature. It can be seen clearly that increasing the annealing temperature results in large-scale grain growth with average grain sizes of $\sim 500 \mathrm{~nm}$ at $350{ }^{\circ} \mathrm{C}$. Further heating does not greatly increase the average grain size, although serveral $1-1.5 \mu \mathrm{m}$ are observed at or above $400{ }^{\circ} \mathrm{C}$.

Scanning Electron Microscopy (SEM) was used to analyze the morphology of the $\mathrm{CuSbS}_{2}$ films at different annealing temperatures. Each film was heated for 30 minutes at the designated temperature. Figure 2 shows top view SEM images of the as-deposited films from $200-450{ }^{\circ} \mathrm{C}$. The as-deposited film at $200{ }^{\circ} \mathrm{C}$ appears porous with no evidence of individual grains. Heating the films to $350{ }^{\circ} \mathrm{C}$ results in a gradual change of the film's morphology from porous to microcrystalline. Clear individual grains with an average size of $\sim 500 \mathrm{~nm}$ in diameter can be seen at $350{ }^{\circ} \mathrm{C}$. Further heating has little effect on the average grain size, however some micron sized grains are observed at $400-450{ }^{\circ} \mathrm{C}$ (see histogram of grain size distribution versus annealing temperature).

Notably, achieving grain growth of metal sulfide semiconductors on this scale with only heat treatment is rare. This may be attributed to the extremely low melting temperature of $\mathrm{CuSbS}_{2}\left(551{ }^{\circ} \mathrm{C}\right)$ compared to other commonly employed solar absorber materials, such as CZTS $\left(990^{\circ} \mathrm{C}\right)$ and CIGS $\left(1070{ }^{\circ} \mathrm{C}\right)$. Although grain growth via simple heat treatment has been observed for analogous systems with low melting points, such as $\mathrm{Sb}_{2} \mathrm{~S}_{3}$ and $\mathrm{Sb}_{2} \mathrm{Se}_{3}{ }^{28,39}$, typically a high temperature chalcogenization step between $500-550{ }^{\circ} \mathrm{C}$ is required to achieve grain growth at this scale for CZTS and

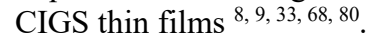

\section{Thin Film Optical and Band Properties}

Having obtained uniform pinhole-free phase-pure $\mathrm{CuSbS}_{2}$ thin films we investigated their optical properties. Figure 3a shows an absorbance spectrum of a typical thin film $(\mathrm{Cu}: \mathrm{Sb}$; $1: 1$, thickness $95 \mathrm{~nm}$, annealed at $350{ }^{\circ} \mathrm{C}$ for $\left.10 \mathrm{~min}\right)$. The absorbance is seen to increase strongly for energies above the band gap $(\sim 800 \mathrm{~nm})$. A plot of the corresponding absorption coefficient as a function of energy is shown in Panel $b$. The absorption coefficient is seen to rise to $\sim 5 \times 10^{4} \mathrm{~cm}^{-1}$ at around $2 \mathrm{eV}$, reaching a maximum of $\sim 8 \times 10^{4} \mathrm{~cm}^{-1}$ at approximately $2.4 \mathrm{eV}$. Next, we evaluated the band gap as a function of annealing (processing) temperature (Panel c). The as-deposited films annealed in air at $200{ }^{\circ} \mathrm{C}$, although known to be quite crystalline from XRD, have a strong indirect character and an intercept of $\sim 1.15 \mathrm{eV}$ (see Panel $\mathrm{d}$ inset). This is somewhat expected given that at such low temperatures the partially sintered films contain numerous defects, which degrade the optoelectronic properties. In sharp contrast, at $250{ }^{\circ} \mathrm{C}$ the films become highly direct in character with an extrapolated direct band gap of $\sim 1.6 \mathrm{eV}$, which is consistent with previous reports on the band gap of $\mathrm{CuSbS}_{2}{ }^{57,69,81}$. The band gap remains almost constant for films treated at temperatures up to $350{ }^{\circ} \mathrm{C}$. Even higher annealing temperatures cause the band gap to decrease slightly $(\sim 40 \mathrm{meV})$ to $\sim 1.56 \mathrm{eV}$ consistent with increased grain growth. Panel d shows a plot of the phase pure films $(\mathrm{Cu}: \mathrm{Sb}$ 0.9:1 and $1: 1)$ annealed at $350{ }^{\circ} \mathrm{C}$. It is apparent from the Tauc analysis that there is no discernible change in band gap within this compositional range with both films having an extrapolated band gap of $1.6 \mathrm{eV}$.

To evaluate the band structure of the films Photoelectron Spectroscopy in Air (PESA) was conducted. Figure 3 Panel e displays the PESA spectra for films treated at various temperatures. The as-deposited pre-annealed sample $\left(200{ }^{\circ} \mathrm{C}\right)$ was found to have a VBM close to $-4.8 \mathrm{eV}$ (relative to the vacuum level), which then decreased to $-4.96 \mathrm{eV}$ for films heated at temperatures above $350{ }^{\circ} \mathrm{C}$. The $\mathrm{VBM}$ of $\mathrm{CuSbS}_{2}$ has been reported over a range of energies between -4.9 and -5.35 $\mathrm{eV}^{6655,82}$. To help clarify these discrepancies we conducted experiments to synthesize "bulk" $\mathrm{CuSbS}_{2}$ as a means to provide our own additional reference. To accomplish this $\mathrm{Cu}, \mathrm{Sb}$ and $\mathrm{S}$ powders were (orbital) ball milled into pure phase $\mathrm{CuSbS}_{2}$ by optimizing the rotation speed and reaction time. It is well established that lattice strain (alterations of the periodic potential), the extent of p-type doping (in this case through copper vacancies) and quantization effects all affect the VBM of semiconductors within $\sim 100 \mathrm{meV}$. As such, the use of pure powders consisting of large crystal grains is likely to provide the most accurate indication of the VBM of a given material. The PESA measurements of the powder samples gave higher energy VBM values consistently between $5.1-5.15 \mathrm{eV}$ (see Supporting Information, Figure S4).

Figure 3: (a) Absorption spectrum of a $\sim 95 \mathrm{~nm} \mathrm{CuSbS} 2$ thin film. (b) Absorption coefficient of the film in panel A. (c) Tauc plot of $\mathrm{CuSbS}_{2}$ thin films heated at different temperatures $(\mathrm{Cu}: \mathrm{Sb} ; 1: 1)$. (d) Tauc plot of copper-poor and stoichiometric $\mathrm{CuSbS}_{2}$ thin films
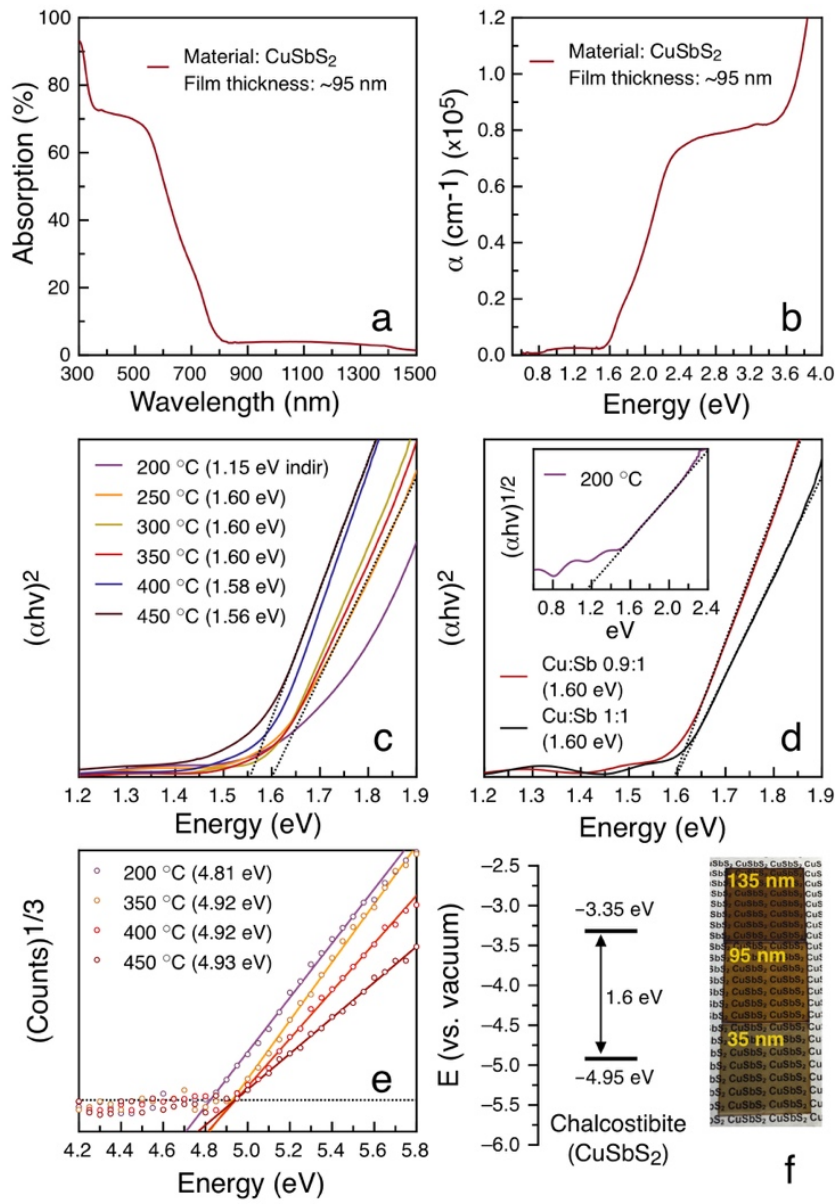

annealed at $350{ }^{\circ} \mathrm{C}$. The inset shows the stoichiometric film at 200 ${ }^{\circ} \mathrm{C}$ showing indirect character with a band gap of $\sim 1.15 \mathrm{eV}$. (e) Photoelectron Spectroscopy in Air (PESA) measurements as a function of annealing temperature $(\mathrm{Cu}: \mathrm{Sb} ; 1: 1)$. (f) Schematic of the band positions of stoichiometric $\mathrm{CuSbS}_{2}$ thin films and images of $\mathrm{CuSbS}_{2}$ thin films with varying thicknesses annealed at $350{ }^{\circ} \mathrm{C}$. 
For inorganic semiconductors the valence band maximum $(\mathrm{VBM})$ and optical band gaps $\left(\mathrm{E}_{\mathrm{g}, \mathrm{opt}}\right)$ can be used to provide a reasonable approximation of the conduction band $(\mathrm{CB})(\mathrm{CB} \approx$ $\left.\mathrm{VB}-\mathrm{E}_{\mathrm{g}, \mathrm{opt}}\right)$. Panel $\mathrm{f}$ shows the band structure of the $\mathrm{CuSbS}_{2}$ thin films investigated in this work. Specifically, the VBM was evaluated as $-4.95 \mathrm{eV}$ and the conduction band minimum at $3.35 \mathrm{eV}$. To highlight the quality of the thin films deposited from the dithiocarbamate precursors, photos of these films with thicknesses of $35 \mathrm{~nm}, 95 \mathrm{~nm}$, and $135 \mathrm{~nm}$ are also shown. Importantly, ultra-thin highly uniform pinhole free films of $\sim 35$ $\mathrm{nm}$ can be readily deposited using the techniques described herein, which is made possible through the use of DTC precursors $^{36}$.

\section{$\mathrm{CuSbS}_{2}$ Thin Film Photo-electrochemistry}

To test the photo-response of the thin films, the molecular precursor solutions were spin coated onto FTO-coated glass
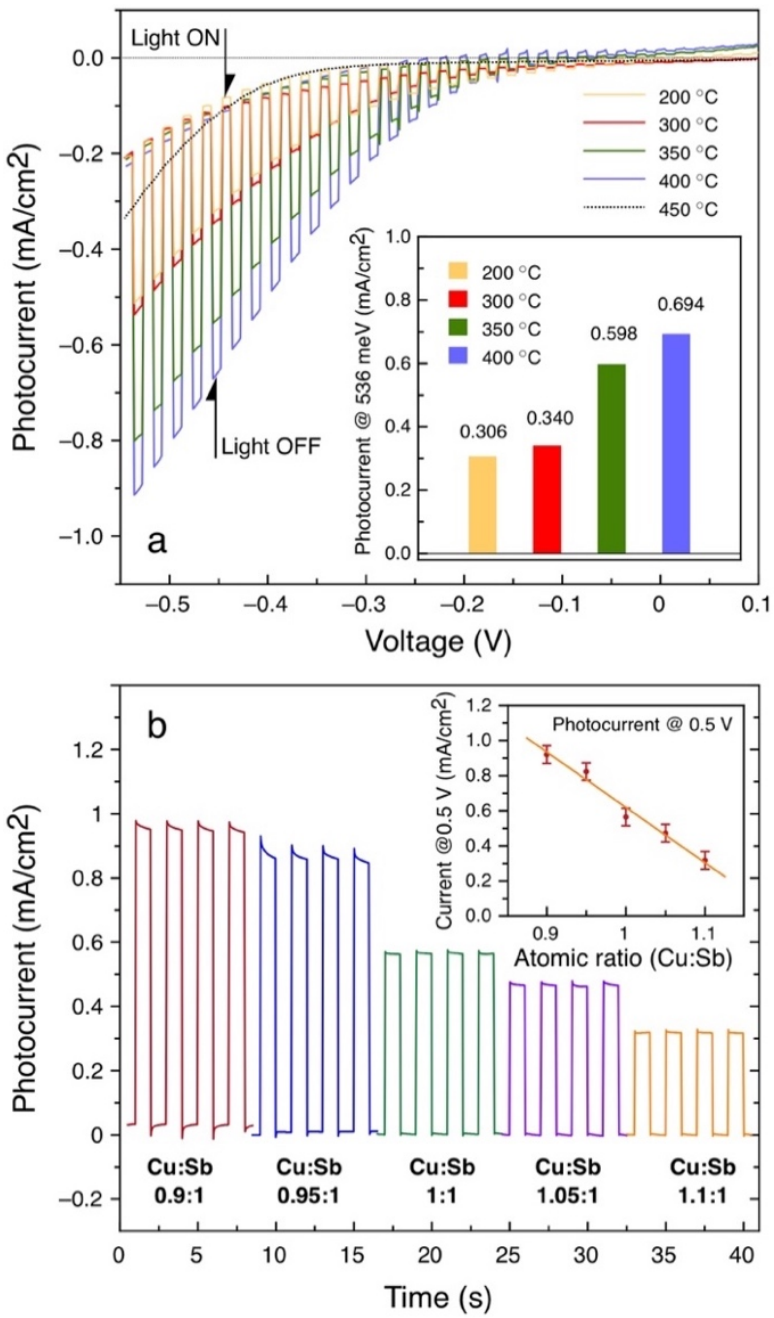

substrates (see the Experimental Section for details). The films (3 layers from $0.1 \mathrm{M}$ solutions to avoid pinholes) were carefully adjusted to similar thicknesses $(150-160 \mathrm{~nm}$ by surface profilometry) to ensure comparable results. These films were mounted to a custom built three-electrode photoelectrochemical cell with a coiled Pt mesh-basket working electrode and a $\mathrm{Ag} / \mathrm{AgCl}$ reference electrode containing an aqueous $\mathrm{Eu}^{3+}$ electrolyte as an electron acceptor similar to previous work ${ }^{42}$. Europium (III) was chosen as it does not absorb light at the probe wavelength and it has a reduction potential energetically below the conduction band edge of $\mathrm{CuSbS}_{2}$, which enables photoreduction.

Photo-electrochemistry is an excellent means to probe the optoelectronic properties of a thin film absorber layer without the complications associated with additional contacts. Photoelectrochemical data, in conjunction with SEM data, provides valuable insights into the conditions required to achieve highperformance photoactive thin films. Figure 4 displays the photo-electrochemistry of stoichiometric $\mathrm{CuSbS}_{2}$ thin films on FTO-coated glass as a function of temperature and composition. Figure $4 \mathrm{a}$ shows the photo-response of $\mathrm{CuSbS}_{2}$ films under chopped light annealed at temperatures between $200-450{ }^{\circ} \mathrm{C}$ in an inert atmosphere. Firstly, it can be seen that the films exhibit a strong p-type photo-response, as indicated by the increased photocurrent under negative bias. Furthermore, the response is rapid with rise/fall times $<<10 \mathrm{~ms}$, which is indicative of low capacitance and rapid charge transport within the film.

Analysis of the data reveals that the photocurrent remains relatively constant for annealing temperatures up to $300{ }^{\circ} \mathrm{C}$. However, increasing the annealing temperature to $350{ }^{\circ} \mathrm{C}$ results in a massive jump in photocurrent ( $45 \%)$. Importantly, this increase is coincident with the onset of grain formation between $300{ }^{\circ} \mathrm{C}$ and $350{ }^{\circ} \mathrm{C}$ as indicated by SEM data. The transition to distinct grains (from the more porous morphology observed at $300{ }^{\circ} \mathrm{C}$ ) typically culminates in a reduction in the number of defect "trap" states within the film and thus improves photo-response. Further heating to $400{ }^{\circ} \mathrm{C}$ reduces the prevalence of grain boundaries and results in a slight further improvement to the photocurrent. The photo-response is seen to be negligible after heating at $450{ }^{\circ} \mathrm{C}$, which places an upper limit on the processing temperature. The inset shows a column graph summarizing the maximum photocurrent achieved (at $536 \mathrm{meV}$ negative bias vs $\mathrm{Ag} / \mathrm{AgCl}$ ) at the different annealing temperatures.

Figure 4: (a) Photo-response of $\mathrm{CuSbS}_{2}$ thin films annealed at various temperatures under chopped light. The films show a strong p-type photocurrent that steadily increases up to annealing temperatures of $400{ }^{\circ} \mathrm{C}$. The inset shows the maximum photocurrent at each temperature. (b) Steady state photocurrent at $-0.5 \mathrm{~V}$ (vs. $\mathrm{Ag} / \mathrm{AgCl}$ ) as a function of composition from copper poor to copper rich. The inset shows the maximum photocurrent as a function of compositional ratio.

To examine the effect of composition on the photocurrent, multiple thin films were prepared with different $\mathrm{Cu}: \mathrm{Sb}$ ratios, ranging from $\mathrm{Cu}$-poor $(\mathrm{Cu}: \mathrm{Sb} ; 0.9: 1)$ to $\mathrm{Cu}$-rich $(\mathrm{Cu}: \mathrm{Sb} ; 1.1: 1)$ Figure $4 \mathrm{~b}$ shows $\sim 8 \mathrm{sec}$ sections of the stabilized photoresponse (at $0.5 \mathrm{~V}$ negative bias vs $\mathrm{Ag} / \mathrm{AgCl}$ ) from $\mathrm{CuSbS}_{2}$ thin films with varying compositions annealed at $350{ }^{\circ} \mathrm{C}$ for $30 \mathrm{~min}$. The compositions were based in the range of $10 \%$ copper poor to $10 \%$ copper rich as these samples gave phase-pure $\mathrm{CuSbS}_{2}$ (with the exception of $\mathrm{Cu}: \mathrm{Sb} ; 1.1: 1$, which is known to precipitate trace $\mathrm{Cu}_{9} \mathrm{~S}_{5}$ impurities, although we expect this impurity to have negligible effect on photocurrent). Analysis of the data reveals a clear trend wherein increasingly copper deficient films were found to exhibit increased photocurrents. Specifically, the stoichiometric sample exhibited a photocurrent of $\sim 0.57 \mathrm{~mA} / \mathrm{cm}^{2}$, which rose to nearly $1 \mathrm{~mA} / \mathrm{cm}^{2}$ for the $10 \%$ $\mathrm{Cu}$-poor film. We may attribute this increase in photo-current to both the increased carrier concentration and $\mathrm{p}$-type nature of the films that contain higher concentrations of copper 

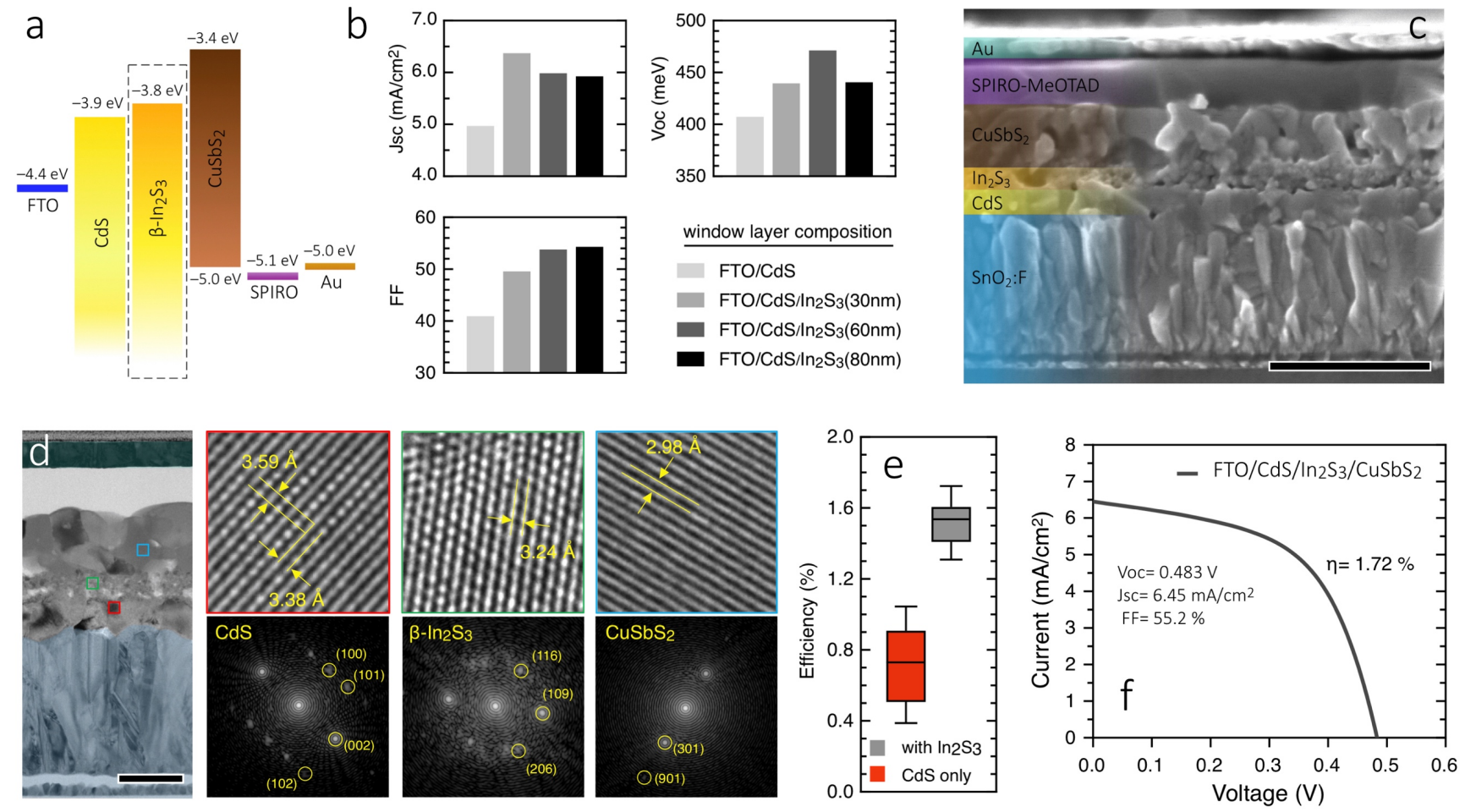

Figure 5: A) Band diagram of the solar cells fabricated in this work. B) Device statistics for solar cells without the $\operatorname{In}_{2} \mathrm{~S}_{3}(\mathrm{CdS}$ only) and with various thicknesses of $\operatorname{In}_{2} S_{3}$ interlayers. C) Cross-section SEM image of a top performing solar cell. Each of the five device layers is clearly visible. Scale bar is $500 \mathrm{~nm}$. D) HRTEM of a focused ion beam cut section of a top-performing solar cell. The regions of interest within each of the key device layers is color coded to the corresponding lattice images and FFTs on the right $\left(\mathrm{CdS}-\mathrm{red}\right.$; In $2 \mathrm{~S}_{3}$-green; $\mathrm{CuSbS}_{2}$-blue). The lattice planes and FFTs confirm the crystallinity of each layer without any notable lattice expansions or contractions due to strain or dopant inclusions. E) Average device power conversion efficiencies for solar cells with and without the $\operatorname{In}_{2} \mathrm{~S}_{3}$ interlayer. F) Current-voltage curve under 1 sun illumination for the champion device.

vacancies $\left(\mathrm{V}_{\mathrm{Cu}}\right)$ in the lattice ${ }^{53,73}$. The inset displays the photocurrent achieved at $0.5 \mathrm{~V}$ negative bias vs $\mathrm{Ag} / \mathrm{AgCl}$ as a function of the $\mathrm{Cu}: \mathrm{Sb}$ atomic ratio. It can be seen clearly that the photo-response increases linearly as the films become more copper deficient. From these data it is evident that $10 \% \mathrm{Cu}$-poor films are the best films for achieving the greatest photoresponse while maintaining phase purity.

\section{$\mathrm{CuSbS}_{2}$ Thin Film Solar Cells}

The optimized $\mathrm{CuSbS}_{2}$ semiconductor thin films prepared were integrated into solar cells. Details on solar cell fabrication can be found in the Experimental Section as well as the effect of additional processing parameters in Supporting Information, Figure S5 and Figure S6. The composition of the $\mathrm{CuSbS}_{2}$ and the processing conditions for the $\mathrm{CuSbS}_{2}$ absorber layer required to achieve optimal cell performance were based on the $\mathrm{XRD}$, SEM, and photo-response data from the photoelectrochemistry experiments collectively.

To begin we fabricated devices with a standard superstrate structure common to CIGS and CdTe solar cells, with an $\mathrm{FTO} / \mathrm{CdS} / \mathrm{CuSbS}_{2} / \mathrm{HTL} / \mathrm{Au}$ architecture. The driving force behind device development was centered on improving the fill factor and open circuit voltage through reductions to the shunt conductance and improving the p-n junction, which are known to be problematic in this specific device structure ${ }^{53,69}$. Due to its $n$-type behavior and favorable band positions, $\operatorname{In}_{2} \mathrm{~S}_{3}$ has been used as a buffer layer both on its own and in tandem with $\mathrm{CdS}$ to improve junction quality and decrease the voltage deficit across a wide range of solar cell types, including CIS, CIGS, and CZTSSe ${ }^{83-86}$. Although popular for other cell types, the use of $\mathrm{In}_{2} \mathrm{~S}_{3}$ buffer layers has yet to be applied to CAS. Figure 5a shows a band diagram of the superstrate solar architecture developed in this work. The use of an optional interlayer of $\mathrm{In}_{2} \mathrm{~S}_{3}$ is highlighted inside the dashed box. The values for the band positions were taken from well-established literature values ${ }^{53,69,85,87}$ and the measurements of $\mathrm{CuSbS}_{2}$ conducted in this work. It can be seen that $\mathrm{CuSbS}_{2} / \mathrm{CdS}$ forms an effective Type II heterojunction and that the introduction of $\operatorname{In}_{2} \mathrm{~S}_{3}$ forms a graded Type II heterojunction both of which are applicable for charge separation and high efficiency devices.

To investigate the effect of introducing an $\operatorname{In}_{2} \mathrm{~S}_{3}$ buffer layer we conducted initial studies to evaluate the effect of buffer layer thickness on device performance. Figure $5 \mathrm{~b}$ shows a bar chart of the averaged cell statistics collected for a series of 20 solar cell devices with a single $\mathrm{CdS}$ window layer and a double $\mathrm{CdS} / \mathrm{In}_{2} \mathrm{~S}_{3}$ window/buffer layer with various $\mathrm{In}_{2} \mathrm{~S}_{3}$ thicknesses. It can be seen that even upon the introduction of an ultrathin $25-30 \mathrm{~nm} \mathrm{In}_{2} \mathrm{~S}_{3}$ interfacial layer there is a pronounced increase in all the key device parameters, in particular the short circuit current, which is indicative of an increased collection probability through reduced interfacial defects and an improved $\mathrm{p}-\mathrm{n}$ junction. This is not surprising as $\mathrm{CdS}$ is known to generate a partially defective junction upon heat treatment with copper- 
based materials ${ }^{88,89}$. Upon the deposition of thicker $\operatorname{In}_{2} \mathrm{~S}_{3}$ layers the Jsc stabilizes and no further enhancements are observed. This also highlights that the $\operatorname{In}_{2} \mathrm{~S}_{3}$ buffer layer does not contribute significantly to the Jsc of the devices. The overall trend in photogenerated current is consistent with the observed increases to the open circuit voltage through a reduced surface recombination at the $\mathrm{In}_{2} \mathrm{~S}_{3}$ interface ${ }^{66}$. Suns-Voc measurements revealed a decay of $\sim 100 \mathrm{meV}$ Voc per decade and a slope of $\sim 1.7 \mathrm{kT} / \mathrm{q}$, indicating further improvements to junction quality are still possible (see Supporting Information, Figure S7).

The fill factor is seen to steadily increase with $\operatorname{In}_{2} \mathrm{~S}_{3}$ layer thickness reaching a plateau at layer thicknesses around $60 \mathrm{~nm}$. Fill factors consistently at or above $50 \%$ for these devices were observed and are among the highest values reported for $\mathrm{CuSbS}_{2}$ solar cells. The largest single contributor to the improved device efficiencies is the vast improvements to fill factor, which are driven mainly through the increased shunt resistance of devices with thicker $\operatorname{In}_{2} \mathrm{~S}_{3}$ layers $\left(185 \Omega / \mathrm{cm}^{2}-\mathrm{CdS}\right.$ only; $401 \Omega / \mathrm{cm}^{2}-$ $\left.30 \mathrm{~nm} \mathrm{In} \mathrm{S}_{3} ; 504 \Omega / \mathrm{cm}^{2}-60 \mathrm{~nm} \mathrm{In}_{2} \mathrm{~S}_{3}\right)$. Modest increases to the average open circuit voltages are also observed $(\sim 65 \mathrm{meV}$ at peak). Solar cells with CdS-only window layers had on average slightly lower reverse saturation current densities than the double window/buffer layer devices. Although slightly higher leakage currents through the junction reduce open circuit voltage, this was offset by the reduced current and highly shunted behavior of the CdS-only devices. From these data it was determined that for the best overall device performance the optimal $\mathrm{In}_{2} \mathrm{~S}_{3}$ thickness is around $50-60 \mathrm{~nm}$.

Figure $5 \mathrm{c}$ shows a cross-section SEM image of a typical topperforming dual window layer solar cell. The solar cell is highly uniform and planar with the morphology of each layer clearly identifiable. For clarity the FTO has been color coded blue, while the other layers are CdS (yellow), $\mathrm{In}_{2} \mathrm{~S}_{3}$ (orange), $\mathrm{CuSbS}_{2}$ (brown), SPIRO-MeOTAD (purple) and the Au top electrode (green). Top view SEM images of the CdS window layer and a typical $\sim 60 \mathrm{~nm} \mathrm{In}_{2} \mathrm{~S}_{3}$ thin film on $\mathrm{CdS}$ can be found in the Supporting Information, Figure S8. To investigate the structure and morphology of the $\mathrm{CuSbS}_{2}$ solar cells in more detail a section of the cell shown in Panel C was cut into a lamella using a Focused Ion Beam SEM (FIBSEM) and subsequently thinned to c.a. $100 \mathrm{~nm}$ using a gallium beam for imaging inside a TEM. Figure 5d shows a HRTEM image of the cell in cross section. The top and bottom electrodes have been highlighted for clarity. From the bottom up these layers are FTO (450 nm); CdS (87 $\mathrm{nm}) ; \mathrm{In}_{2} \mathrm{~S}_{3}(59 \mathrm{~nm}) \mathrm{CuSbS}_{2}(172 \mathrm{~nm})$; SPIRO-MeOTAD ( 125 $\mathrm{nm}) ; \mathrm{Au}(\sim 70 \mathrm{~nm})$. Close inspection of the cross section reveals that the $\mathrm{CdS}$ and $\mathrm{CuSbS}$ layers are highly dense while the $\mathrm{In}_{2} \mathrm{~S}_{3}$ layer has a more nanostructured morphology (this can also be observed in the cross-section SEM). Within the lamella a segment of each layer was analyzed to determine its crystallinity, phase purity, and the presence of any lattice strain after the processing of the solar cell devices.

The key regions of analysis correspond to CdS (red box), $\mathrm{In}_{2} \mathrm{~S}_{3}$ (green box), and $\mathrm{CuSbS}_{2}$ (blue box). Analysis of the CdS layer reveals a perfect match to wurtzite hexagonal $\mathrm{CdS}$ with measured lattice spacings of $3.59 \AA$ and $3.38 \AA$. These match well to the (100) and (002) orthogonal lattice planes of hexagonal CdS with d-spacings of $3.586 \AA$ and $3.359 \AA$ respectively. The corresponding FFT also shows consistent (101) and (102) spacings. These results corroborate the bulk XRD analysis of the as-prepared CdS thin films (see Supporting Information, Figure S9). Analysis of the $\operatorname{In}_{2} \mathrm{~S}_{3}$ layer shows a lattice spacing of $3.24 \AA$, which matches to the expected 3.249 $\AA \mathrm{d}$-spacing of the dominant (109) lattice plane of tetragonal $ß$ $\mathrm{In}_{2} \mathrm{~S}_{3}$. Likewise, the corresponding FFT gives the correct positions for the lower intensity (116) and (206) lattice planes. As expected from XRD, the high-resolution imaging of the $\mathrm{CuSbS}_{2}$ layer reveals that the layer is highly crystalline with clearly visible lattice planes. The recurrent lattice spacing observed throughout the layer was $2.98 \AA$, corresponding to the (301) of orthorhombic $\mathrm{CuSbS}_{2}(100 \%$ intensity according to PDF 44-1417), expected d-spacing $2.985 \AA$ ). Larger areas are shown in Supporting Information, Figure S10. The lattice spacing of all crystalline regions were calculated from an average of 20 or more consecutive lattice planes. From the clearly defined layered structure observed in the HRTEM crosssection and the close match of the d-spacings in the highresolution lattice images to their expected values we observe that the materials are not significantly strained by anomalous doping and that the interfaces are well maintained after device assembly.

Figure 5e shows the comparative efficiency statistics of devices with and without the optimal $60 \mathrm{~nm} \operatorname{In}_{2} \mathrm{~S}_{3}$ interlayer. These statistics were developed from 24 solar cells of each type. It is immediately evident that the solar cells have improved efficiencies upon the introduction of the $\operatorname{In}_{2} \mathrm{~S}_{3}$ interlayer as discussed previously. The median cell efficiencies with $\mathrm{CdS}$ and $\mathrm{CdS} / \mathrm{In}_{2} \mathrm{~S}_{3}$ were $0.73 \%$ and $1.54 \%$, with the champion cells of each type reaching $1.04 \%$ and $1.72 \%$ respectively. The full cell statistics can be found in the Supporting Information, Figure S11. Figure $5 \mathrm{f}$ shows the current-voltage curve for the champion device with $\mathrm{CdS} / \mathrm{In}_{2} \mathrm{~S}_{3}$ window/buffer layer structure $\left(\mathrm{Voc}=0.483 \mathrm{~V} ; \mathrm{Jsc}=6.45 \mathrm{~mA} / \mathrm{cm}^{2} ; \mathrm{FF}=55.2 \% ; \mathrm{PCE}=1.72 \%\right)$. These results are the highest efficiency solution-processed planar $\mathrm{CuSbS}_{2}$ solar cells to date, with over three times the efficiency of the current best hydrazine-based methods, and over double the previous record for thin film solar cells of any other MP-based method. A table outlining comparative performances of record efficiency solution processed $\mathrm{CuSbS}_{2}$ solar cells to date can be viewed in the Supporting Information, Table S3. The efficiencies achieved in this work are validation of both the high quality of the carefully optimized thin films and interlayer strategy outlined herein.

\section{Conclusions}

We have presented a method to achieve high-quality semiconductor thin films of $\mathrm{CuSbS}_{2}$ at mild processing temperatures. Unlike existing thiourea-based precursors, the low decomposition temperature and balanced reactivity of metal-DTC precursors yielded high quality films and phasepure materials at low temperatures. Micrometer-sized grains could be achieved without the need for multistep procedures or high temperature sulfurization, which represents a significant advantage in the rapid processing of devices using $\mathrm{CuSbS}_{2}$ photoactive layers. Through careful optimization of the cation ratio and annealing steps phase-pure p-type $\mathrm{CuSbS}_{2}$ thin films with high photoconductivity have been demonstrated. These optimized films were incorporated into superstrate structured solar cell devices that reached $1.7 \%$. Improvements to device efficiency were realized through the use of an $\operatorname{In}_{2} \mathrm{~S}_{3}$ buffer electron transport layer. The devices fabricated here are the highest efficiency solution-processed planar $\mathrm{CuSbS}_{2}$ solar cells to date. Further improvements could be realized by using thinner and denser $\operatorname{In}_{2} \mathrm{~S}_{3}$ layers. We are confident that the facile sulfurization-free methods to produce high-quality $\mathrm{CuSbS}_{2}$ thin 
films outlined here will prove invaluable to furthering the advancement of thin films devices and solar cells.

\section{EXPERIMENTAL}

Materials:

Copper(I) oxide (99.999\%), antimony(III) oxide (99.999\%), butylamine (99.5\%), ethanol (dry absolute), europium(III) chloride hexahydrate (99.9\%), copper metal (99.999\%), and antimony metal (99.999\%) were procured from Sigma Aldrich. Carbon disulfide (99.9\%) was purchased from Merck. 2,2',7,7'-Tetrakis-(N,N-di-4-methoxyphenyl amino)9,9'-spirobifluorene (SPIRO-MeOTAD) was purchased from Lumtec. FTO-coated glass was purchased from Latech Scientific Supply $(15 \Omega / \square)$. All reagents and solvents were used as received without further purification.

\section{Precursor Solutions:}

Full details on the preparation of the copper and antimony dithiocarbamate molecular precursor solutions can be found in the Supporting Information.

\section{Window and Buffer Layer Fabrication:}

The method used to fabricate of CdS thin films via chemical bath deposition (CBD) was reported previously ${ }^{8}$. The asprepared films were treated sequentially with $\mathrm{H}_{2} \mathrm{O}_{2}$ and $\mathrm{CdCl}_{2}$ in methanol sequentially and them heated in air at $400{ }^{\circ} \mathrm{C}$ for 5 mins. See Supporting Information for details. The $\operatorname{In}_{2} \mathrm{~S}_{3}$ thin films were spun onto $\mathrm{FTO} / \mathrm{CdS}$ substrates from a $0.1 \mathrm{M}$ ethanolic indium butyldithiocarbamate (In-DTC molecular precursor;) solution made from $\operatorname{In}(\mathrm{OH})_{3}$, butylamine, and $\mathrm{CS}_{2}$ to afford a final In:DTC ratio of 1:6. After 2 days of stirring, the solution of indium butyldithiocarbamate was filtered to remove residual $\mathrm{In}(\mathrm{OH})_{3}$ and the concentration adjusted to provide the required layer thicknesses as measured by profilometry.

\section{$\mathrm{CuSbS}_{2}$ Thin Film Fabrication:}

To produce an $\sim 100 \mathrm{~nm}$ film a $0.1 \mathrm{M} \mathrm{Cu} / \mathrm{Sb}$ precursor solution was pipetted onto FTO-coated glass substrates and spun at $2000 \mathrm{rpm}$ for $30 \mathrm{sec}$, followed by a drying/ decomposition step at $200{ }^{\circ} \mathrm{C}$. Heating at $200{ }^{\circ} \mathrm{C}$ resulted in an immediate color change from clear/yellow to dark brown, indicating the decomposition of the metal dithiocarbamate precursors to form $\mathrm{CuSbS}_{2}$ (see Figure 1a). Unless otherwise stated all films were heated at $200{ }^{\circ} \mathrm{C}$ for $10 \mathrm{~min}$ in air followed by transfer to a nitrogen glovebox for final annealing at the specified temperatures for the specified times. We note here that the use of a pure Sb-DTC precursor resulted in the fabrication of well-formed pure-phase $\mathrm{Sb}_{2} \mathrm{~S}_{3}$ thin films (See Supporting Information, Figure S12).

\section{Instrumentation:}

UV-vis-NIR absorption spectra of the thin films were collected at room temperature using a PerkinElmer Lambda 1050 spectrophotometer with an integrating sphere attachment. X-ray diffraction (XRD) was performed on a Bruker D8 diffractometer equipped with a $\mathrm{Cu} \mathrm{K} \alpha$ radiation source and operated at $40 \mathrm{kV}$ and $40 \mathrm{~mA}$. X-ray photoelectron spectroscopy (XPS) was performed on a Kratos Axis HSi using an $\mathrm{Al} \mathrm{K} \alpha \mathrm{X}$-ray source. Photoelectron spectroscopy in air (PESA) measurements were performed on a Riken Keiki AC-2 spectrophotometer. Scanning electron micrographs were collected on a FEI Nova NanoSEM 200 FEGSEM. Lamella cutting was performed using a gallium ion beam in a FEI Scios
Dualbeam FIBSEM. Images were conducted in a JEOL $2100 \mathrm{~F}$ FEGTEM/STEM equipped with a Gatan OneView 4k CCD Camera. Evaporations were conducted using a Daedong HighTechnologies Solar-Bridge thermal evaporator system.

Photo-Electrochemistry:

The films were fixed to a custom-built electrochemical cell, which consisted of a mesh-basket platinum working electrode and an $\mathrm{Ag} / \mathrm{AgCl}$ reference electrode. The voltage of the cell was manipulated using a Powerlab 4/20 controlled using EChem software (ver. 1.5.2, AD Instruments). The light source consisted of a $455 \mathrm{~nm}$ blue LED (LUXEON "Royal Blue") equipped with a diffuser. The sample was illuminated through the FTO onto the back contact. The light intensity at the sample was measured using a Hamamatsu silicon photodiode $(0.43 \mathrm{~mA}$ on $6.6 \mathrm{~mm}^{2}$ ). The calculated light intensity from calibration curves yielded $\sim 1.85 \mathrm{~mW}$ incident upon the photo-diode corresponding to a total flux of $\sim 28 \mathrm{mWcm}^{-2}$.

\section{Solar Cell Fabrication and Measurement:}

Solar cells were fabricated in the following architecture: FTO (450 nm); CdS ( 90 nm); $\operatorname{In}_{2} \mathrm{~S}_{3}(\sim 60 \mathrm{~nm}) \mathrm{CuSbS}_{2}(\sim 180$ $\mathrm{nm})$; SPIRO-MeOTAD $(\sim 125 \mathrm{~nm})$; Au $(\sim 70 \mathrm{~nm})$. Firstly, CdS was deposited on FTO by chemical bath deposition (CBD) and treated as described previously. Next, the buffer layer was deposited and annealed at $400{ }^{\circ} \mathrm{C}$ in the glove box for 5 mins. Then the absorber layer was deposited layer-by-layer by spin coating three layers $(4000 \mathrm{rpm}, 30 \mathrm{sec})$ of $0.075 \mathrm{M} \mathrm{Cu} / \mathrm{Sb}$ precursor solution $(\mathrm{Cu}: \mathrm{Sb} ; 0.9: 1)$ with a decomposition step at $200{ }^{\circ} \mathrm{C}$ between each layer. The final three-layer structure was annealed at $350{ }^{\circ} \mathrm{C}$ for $2 \mathrm{~min}$, achieving a final thickness of $\sim 180 \mathrm{~nm}$. Next, the hole extraction layer (SPIRO MeOTAD) was deposited by spin coating $(3000 \mathrm{rpm}, 30 \mathrm{sec})$ a solution consisting of $80 \mathrm{mg} / \mathrm{mL}$ SPIRO-MeOTAD in chlorobenzene, $11 \mu \mathrm{L}$ of $520 \mathrm{mg} / \mathrm{mL}$ bis(trifluoromethane) sulfonimide lithium salt (Li-TIFSI) and $11 \mu \mathrm{L}$ 4-tert-butylpyridine (TBP). Finally, the gold electrodes were deposited by thermal evaporation through a shadow mask. Measurements were conducted via illumination (Oriel Sol3A Class AAA Solar Simulator) through a laser cut mask $\left(0.100 \mathrm{~cm}^{2}\right)$ using a custom-built set up and a Keithley 2401 Source Meter following the guidelines for best measurement technique ${ }^{90}$.

\section{ASSOCIATED CONTENT}

\section{Supporting Information}

Synthetic procedure for MP inks as well as additional experiments and analysis, including XRD, SEM, HRTEM, XPS, PESA. The Supporting Information is available free of charge on the ACS Publications website.

\section{AUTHOR INFORMATION}

\section{Corresponding Author}

* joel.vanembden@rmit.edu.au

\section{Notes}

The authors declare no competing financial interests.

\section{ACKNOWLEDGMENT}

J.v.E, E.D.G, J.J.J, and A.S.R.C acknowledge the Australian Research Council for funding through grants DE150100427, 
DE170100164, CE170100026, and DE130100635, respectively. E.D.G also acknowledges funding through the Vice-Chancellor Research Fellowship scheme of RMIT University. J.v.E and E.D.G acknowledge funding from the Office of the Chief Executive through the CSIRO Manufacturing Flagship. The authors acknowledge the help of Dr Matthew Field and Dr Edwin Mayes and the use of facilities within the RMIT Microscopy and Microanalysis Facility.

\section{REFERENCES}

1. McDonald, S. A.; Konstantatos, G.; Zhang, S.; Cyr, P. W.; Klem, E. J. D.; Levina, L.; Sargent, E. H., Solution-processed $\mathrm{PbS}$ quantum dot infrared photodetectors and photovoltaics. Nature Materials 2005, 4, (2), 138-142.

2. Dou, L.; Yang, Y.; You, J.; Hong, Z.; Chang, W.-H.; Li, G.; Yang, Y., Solution-processed hybrid perovskite photodetectors with high detectivity. Nature Communications 2014, 5, 5404.

3. Jin, Y.; Wang, J.; Sun, B.; Blakesley, J. C.; Greenham, N. C., Solution-Processed Ultraviolet Photodetectors Based on Colloidal ZnO Nanoparticles. Nano Letters 2008, 8, (6), 16491653.

4. Kaempgen, M.; Chan, C. K.; Ma, J.; Cui, Y.; Gruner, G., Printable Thin Film Supercapacitors Using Single-Walled Carbon Nanotubes. Nano Letters 2009, 9, (5), 1872-1876.

5. Cargnello, M.; Jaén, J. J. D.; Garrido, J. C. H.; Bakhmutsky, K.; Montini, T.; Gámez, J. J. C.; Gorte, R. J.; Fornasiero, P., Exceptional Activity for Methane Combustion over Modular Pd@CeO2 Subunits on Functionalized A12O3. Science 2012, 337, (6095), 713.

6. Sunada, K.; Kikuchi, Y.; Hashimoto, K.; Fujishima, A., Bactericidal and Detoxification Effects of TiO2 Thin Film Photocatalysts. Environmental Science \& Technology 1998, 32, (5), 726-728.

7. Jumabekov, A. N.; Della Gaspera, E.; Xu, Z. Q.; Chesman, A. S. R.; van Embden, J.; Bonke, S. A.; Bao, Q.; Vak, D.; Bach, U., Back-contacted hybrid organic-inorganic perovskite solar cells. Journal of Materials Chemistry C 2016, 4, (15), 31253130 .

8. $\quad$ van Embden, J.; Chesman, A. S. R.; Della Gaspera, E.; Duffy, N. W.; Watkins, S. E.; Jasieniak, J. J., Cu2ZnSnS4xSe4(1$\mathrm{x})$ Solar Cells from Polar Nanocrystal Inks. Journal of the American Chemical Society 2014, 136, (14), 5237-5240.

9. Uhl, A. R.; Katahara, J. K.; Hillhouse, H. W., Molecularink route to $13.0 \%$ efficient low-bandgap $\mathrm{CuIn}(\mathrm{S}, \mathrm{Se}) 2$ and $14.7 \%$ efficient $\mathrm{Cu}(\mathrm{In}, \mathrm{Ga})(\mathrm{S}, \mathrm{Se}) 2$ solar cells. Energy \& Environmental Science 2016, 9, (1), 130-134.

10. Burschka, J.; Pellet, N.; Moon, S.-J.; Humphry-Baker, R.; Gao, P.; Nazeeruddin, M. K.; Grätzel, M., Sequential deposition as a route to high-performance perovskite-sensitized solar cells. Nature 2013, 499, 316.

11. Pavaskar, N. R.; Menezes, C. A.; Sinha, A. P. B., Photoconductive CdS Films by a Chemical Bath Deposition Process. Journal of The Electrochemical Society 1977, 124, (5), 743-748.

12. Chang, J. A.; Rhee, J. H.; Im, S. H.; Lee, Y. H.; Kim, H.j.; Seok, S. I.; Nazeeruddin, M. K.; Gratzel, M., High-Performance Nanostructured Inorganic-Organic Heterojunction Solar Cells. Nano Letters 2010, 10, (7), 2609-2612.

13. Della Gaspera, E.; Kennedy, D. F.; van Embden, J.; Chesman, A. S. R.; Gengenbach, T. R.; Weber, K.; Jasieniak, J. J., Flash-Assisted Processing of Highly Conductive Zinc Oxide Electrodes from Water. Advanced Functional Materials 2015, 25 , (47), 7263-7271.

14. Della Gaspera, E.; van Embden, J.; Chesman, A. S. R.; Duffy, N. W.; Jasieniak, J. J., Mimicry of Sputtered i-ZnO Thin
Films Using Chemical Bath Deposition for Solution-Processed Solar Cells. ACS Applied Materials \& Interfaces 2014, 6, (24), 22519-22526.

15. Nair, P. K.; Nair, M. T. S.; García, V. M.; Arenas, O. L.; Peña, A. C. Y.; Ayala, I. T.; Gomezdaza, O.; Sánchez, A.; Campos, J.; Hu, H.; Suárez, R.; Rincón, M. E., Semiconductor thin films by chemical bath deposition for solar energy related applications. Solar Energy Materials and Solar Cells 1998, 52, (3), 313-344.

16. Tsin, F.; Venerosy, A.; Vidal, J.; Collin, S.; Clatot, J.; Lombez, L.; Paire, M.; Borensztajn, S.; Broussillou, C.; Grand, P. P.; Jaime, S.; Lincot, D.; Rousset, J., Electrodeposition of ZnO window layer for an all-atmospheric fabrication process of chalcogenide solar cell. Scientific reports 2015, 5, 8961.

17. Juškėnas, R.; Niaura, G.; Mockus, Z.; Kanapeckaite, S.; Giraitis, R.; Kondrotas, R.; Naujokaitis, A.; Stalnionis, G.; Pakštas, V.; Karpavičiene, V., XRD studies of an electrochemically codeposited $\mathrm{Cu}-\mathrm{Zn}-\mathrm{Sn}$ precursor and formation of a $\mathrm{Cu} 2 \mathrm{ZnSnSe} 4$ absorber for thin-film solar cells. Journal of Alloys and Compounds 2016, 655, 281-289.

18. Golden, T. D.; Shumsky, M. G.; Zhou, Y.; VanderWerf, R. A.; Van Leeuwen, R. A.; Switzer, J. A., Electrochemical Deposition of Copper(I) Oxide Films. Chemistry of Materials 1996, 8, (10), 2499-2504.

19. Pathan, H. M.; Lokhande, C. D., Deposition of metal chalcogenide thin films by successive ionic layer adsorption and reaction (SILAR) method. Bulletin of Materials Science 2004, 27, (2), 85-111.

20. Chatterjee, S.; Saha, S. K.; Pal, A. J., Formation of alloxide solar cells in atmospheric condition based on $\mathrm{Cu} 2 \mathrm{O}$ thinfilms grown through SILAR technique. Solar Energy Materials and Solar Cells 2016, 147, 17-26.

21. Pathan, H. M.; Sankapal, B. R.; Desai, J. D.; Lokhande, C. D., Preparation and characterization of nanocrystalline CdSe thin films deposited by SILAR method. Materials Chemistry and Physics 2003, 78, (1), 11-14.

22. Panthani, M. G.; Akhavan, V.; Goodfellow, B.; Schmidtke, J. P.; Dunn, L.; Dodabalapur, A.; Barbara, P. F.; Korgel, B. A., Synthesis of CuInS2, CuInSe2, and $\mathrm{Cu}(\mathrm{InxGa1-}$ $\mathrm{x}) \mathrm{Se} 2$ (CIGS) Nanocrystal "Inks" for Printable Photovoltaics. Journal of the American Chemical Society 2008, 130, (49), 1677016777.

23. Paglia, F.; Vak, D.; van Embden, J.; Chesman, A. S. R.; Martucci, A.; Jasieniak, J. J.; Della Gaspera, E., Photonic Sintering of Copper through the Controlled Reduction of Printed $\mathrm{CuO}$ Nanocrystals. ACS Applied Materials \& Interfaces 2015, 7, (45), 25473-25478.

24. Carey, G. H.; Abdelhady, A. L.; Ning, Z.; Thon, S. M.; Bakr, O. M.; Sargent, E. H., Colloidal Quantum Dot Solar Cells. Chemical Reviews 2015, 115, (23), 12732-12763.

25. Bernechea, M.; Miller, N. C.; Xercavins, G.; So, D.; Stavrinadis, A.; Konstantatos, G., Solution-processed solar cells based on environmentally friendly AgBiS2 nanocrystals. Nature Photonics 2016, 10, 521.

26. Kadlag, K. P.; Patil, P.; Jagadeeswara Rao, M.; Datta, S.; Nag, A., Luminescence and solar cell from ligand-free colloidal AgInS2 nanocrystals. CrystEngComm 2014, 16, (17), 3605-3612.

27. Chakraborty, R.; Sim, K. M.; Shrivastava, M.; Adarsh, K. V.; Chung, D. S.; Nag, A., Colloidal Synthesis, Optical Properties, and Hole Transport Layer Applications of Cu2BaSnS4 (CBTS) Nanocrystals. ACS Applied Energy Materials 2019, 2, (5), 3049-3055

28. Yang, B.; Xue, D.-J.; Leng, M.; Zhong, J.; Wang, L.; Song, H.; Zhou, Y.; Tang, J., Hydrazine solution processed Sb2S3, $\mathrm{Sb} 2 \mathrm{Se} 3$ and $\mathrm{Sb} 2(\mathrm{~S} 1-\mathrm{xSex}) 3$ film: molecular precursor identification, film fabrication and band gap tuning. Scientific reports 2015, 5, 10978. 
29. MacInnes, A. N.; Power, M. B.; Hepp, A. F.; Barron, A. $\mathrm{R}$, Indium tert-butylthiolates as single source precursors for indium sulfide thin films: Is molecular design enough? Journal of Organometallic Chemistry 1993, 449, (1), 95-104.

30. Marchand, P.; Carmalt, C. J., Molecular precursor approach to metal oxide and pnictide thin films. Coordination Chemistry Reviews 2013, 257, (23), 3202-3221.

31. Ramasamy, K.; Malik, M. A.; Helliwell, M.; Raftery, J.; O'Brien, P., Thio- and Dithio-Biuret Precursors for Zinc Sulfide, Cadmium Sulfide, and Zinc Cadmium Sulfide Thin Films. Chemistry of Materials 2011, 23, (6), 1471-1481.

32. Chung, C.-H.; Li, S.-H.; Lei, B.; Yang, W.; Hou, W. W.; Bob, B.; Yang, Y., Identification of the Molecular Precursors for Hydrazine Solution Processed $\mathrm{CuIn}(\mathrm{Se}, \mathrm{S}) 2$ Films and Their Interactions. Chemistry of Materials 2011, 23, (4), 964-969.

33. Tian, Q.; Huang, L.; Zhao, W.; Yang, Y.; Wang, G.; Pan, D., Metal sulfide precursor aqueous solutions for fabrication of $\mathrm{Cu} 2 \mathrm{ZnSn}(\mathrm{S}, \mathrm{Se}) 4$ thin film solar cells. Green Chemistry 2015, 17, (2), 1269-1275.

34. Zhao, X.; Lu, M.; Koeper, M. J.; Agrawal, R., Solutionprocessed sulfur depleted $\mathrm{Cu}(\mathrm{In}, \mathrm{Ga}) \mathrm{Se} 2$ solar cells synthesized from a monoamine-dithiol solvent mixture. Journal of Materials Chemistry A 2016, 4, (19), 7390-7397.

35. Xie, Y.; Chen, H.; Li, A.; Zhu, X.; Zhang, L.; Qin, M.; Wang, Y.; Liu, Y.; Huang, F., A facile molecular precursor-based $\mathrm{Cu}(\mathrm{In}, \mathrm{Ga})(\mathrm{S}, \mathrm{Se}) 2$ solar cell with $8.6 \%$ efficiency. Journal of Materials Chemistry A 2014, 2, (33), 13237-13240.

36. van Embden, J.; Della Gaspera, E., Ultrathin Solar Absorber Layers of Silver Bismuth Sulfide from Molecular Precursors. ACS Applied Materials \& Interfaces 2019, 11, (18), 16674-16682.

37. Zhou, Y.; Leng, M.; Xia, Z.; Zhong, J.; Song, H.; Liu, X.; Yang, B.; Zhang, J.; Chen, J.; Zhou, K.; Han, J.; Cheng, Y.; Tang, J., Solution-Processed Antimony Selenide Heterojunction Solar Cells. Advanced Energy Materials 2014, 4, (8), 1301846.

38. Li, S. a.; Zhang, Y.; Tang, R.; Wang, X.; Zhang, T.; Jiang, G.; Liu, W.; Zhu, C.; Chen, T., Aqueous-Solution-Based Approach Towards Carbon-Free Sb2S3 Films for High Efficiency Solar Cells. ChemSusChem 2018, 11, (18), 3208-3214.

39. Wang, X.; Li, J.; Liu, W.; Yang, S.; Zhu, C.; Chen, T., A fast chemical approach towards $\mathrm{Sb} 2 \mathrm{~S} 3$ film with a large grain size for high-performance planar heterojunction solar cells. Nanoscale 2017, 9, (10), 3386-3390.

40. O'Mahony, F. T. F.; Cappel, U. B.; Tokmoldin, N.; Lutz, T.; Lindblad, R.; Rensmo, H.; Haque, S. A., Low-Temperature Solution Processing of Mesoporous Metal-Sulfide Semiconductors as Light-Harvesting Photoanodes. Angewandte Chemie International Edition 2013, 52, (46), 12047-12051.

41. van Embden, J.; Tachibana, Y., Synthesis and characterisation of famatinite copper antimony sulfide nanocrystals. Journal of Materials Chemistry 2012, 22, (23), 11466.

42. van Embden, J.; Latham, K.; Duffy, N. W.; Tachibana, Y., Near-infrared absorbing Cu12Sb4S13 and Cu3SbS4 nanocrystals: synthesis, characterization, and photoelectrochemistry. Journal of the American Chemical Society 2013, 135, (31), 11562-71.

43. Chen, K.; Zhou, J.; Chen, W.; Zhou, P.; He, F.; Liu, Y., Size-Dependent Synthesis of Cu12Sb4S13 Nanocrystals with Bandgap Tunability. Particle \& Particle Systems Characterization 2015, 32, (11), 999-1005.

44. Wang, L.; Yang, B.; Xia, Z.; Leng, M.; Zhou, Y.; Xue, D.-J.; Zhong, J.; Gao, L.; Song, H.; Tang, J., Synthesis and characterization of hydrazine solution processed $\mathrm{Cu} 12 \mathrm{Sb} 4 \mathrm{~S} 13$ film. Solar Energy Materials and Solar Cells 2016, 144, 33-39.

45. Nasonova, D. I.; Verchenko, V. Y.; Tsirlin, A. A.; Shevelkov, A. V., Low-Temperature Structure and Thermoelectric
Properties of Pristine Synthetic Tetrahedrite Cu12Sb4S13. Chemistry of Materials 2016, 28, (18), 6621-6627.

46. Crespo, C. T., Microscopic Optical Absorption, Analysis, and Applications of Famatinite Cu3SbS4. The Journal of Physical Chemistry C 2016, 120, (15), 7959-7965.

47. Ramasamy, K.; Sims, H.; Butler, W. H.; Gupta, A., Mono-, Few-, and Multiple Layers of Copper Antimony Sulfide (CuSbS2): A Ternary Layered Sulfide. Journal of the American Chemical Society 2014, 136, (4), 1587-1598.

48. $\quad$ Yan, C.; Su, Z.; Gu, E.; Cao, T.; Yang, J.; Liu, J.; Liu, F.; Lai, Y.; Li, J.; Liu, Y., Solution-based synthesis of chalcostibite (CuSbS2) nanobricks for solar energy conversion. RSC Advances 2012, 2, (28), 10481-10484.

49. Garza, C.; Shaji, S.; Arato, A.; Perez Tijerina, E.; Alan Castillo, G.; Das Roy, T. K.; Krishnan, B., p-Type CuSbS2 thin films by thermal diffusion of copper into Sb2S3. Solar Energy Materials and Solar Cells 2011, 95, (8), 2001-2005.

50. Edley, M. E.; Opasanont, B.; Conley, J. T.; Tran, H.; Smolin, S. Y.; Li, S.; Dillon, A. D.; Fafarman, A. T.; Baxter, J. B., Solution processed CuSbS2 films for solar cell applications. Thin Solid Films 2018, 646, 180-189.

51. Ramasamy, K.; Sims, H.; Butler, W. H.; Gupta, A., Selective Nanocrystal Synthesis and Calculated Electronic Structure of All Four Phases of Copper-Antimony-Sulfide. Chemistry of Materials 2014, 26, (9), 2891-2899.

52. Qiu, X.; Ji, S.; Chen, C.; Liu, G.; Ye, C., Synthesis, characterization, and surface-enhanced Raman scattering of near infrared absorbing Cu3SbS3 nanocrystals. CrystEngComm 2013 , 15, (48), 10431-10434.

53. Yang, B.; Wang, L.; Han, J.; Zhou, Y.; Song, H.; Chen, S.; Zhong, J.; Lv, L.; Niu, D.; Tang, J., CuSbS2 as a Promising Earth-Abundant Photovoltaic Absorber Material: A Combined Theoretical and Experimental Study. Chemistry of Materials 2014, 26, (10), 3135-3143.

54. McCarthy, C. L.; Cottingham, P.; Abuyen, K.; Schueller, E. C.; Culver, S. P.; Brutchey, R. L., Earth abundant CuSbS2 thin films solution processed from thiol-amine mixtures. Journal of Materials Chemistry C 2016, 4, (26), 6230-6233.

55. Whittles, T. J.; Veal, T. D.; Savory, C. N.; Welch, A. W.; de Souza Lucas, F. W.; Gibbon, J. T.; Birkett, M.; Potter, R. J.; Scanlon, D. O.; Zakutayev, A.; Dhanak, V. R., Core Levels, Band Alignments, and Valence-Band States in CuSbS2 for Solar Cell Applications. ACS Applied Materials \& Interfaces 2017, 9, (48), 41916-41926.

56. Yuan, M.; Mitzi, D. B.; Liu, W.; Kellock, A. J.; Chey, S. J.; Deline, V. R., Optimization of CIGS-Based PV Device through Antimony Doping. Chemistry of Materials 2010, 22, (2), 285-287. 57. Peccerillo, E.; Durose, K., Copper-antimony and copper-bismuth chalcogenides-Research opportunities and review for solar photovoltaics. MRS Energy \& Sustainability 2018, 5, E13.

58. Liu, Y.; Chen, C.; Zhou, Y.; Kondrotas, R.; Tang, J., Butyldithiocarbamate acid solution processing: its fundamentals and applications in chalcogenide thin film solar cells. Journal of Materials Chemistry C 2019, 7, (36), 11068-11084.

59. Han, G.; Won Lee, J.; Kim, J., Fabrication and Characterization of Cu3SbS4 Solar Cell with Cd-free Buffer. 2018; Vol. 73, p 1794-1798.

60. Maiello, P.; Zoppi, G.; Miles, R. W.; Pearsall, N.; Forbes, I., Chalcogenisation of $\mathrm{Cu}-\mathrm{Sb}$ metallic precursors into $\mathrm{Cu} 3 \mathrm{Sb}(\operatorname{SexS} 1-\mathrm{x}) 3$. Solar Energy Materials and Solar Cells 2013, 113, 186-194.

61. Banu, S.; Ahn, S. J.; Ahn, S. K.; Yoon, K.; Cho, A., Fabrication and characterization of cost-efficient CuSbS2 thin film solar cells using hybrid inks. Solar Energy Materials and Solar Cells 2016, 151, 14-23. 
62. Saragih, A. D.; Kuo, D.-H.; Tuan, T. T. A., Thin film solar cell based on p-CuSbS2 together with $\mathrm{Cd}$-free GaN/InGaN bilayer. Journal of Materials Science: Materials in Electronics 2017, 28, (3), 2996-3003.

63. Wan, L.; Ma, C.; Hu, K.; Zhou, R.; Mao, X.; Pan, S.; Wong, L. H.; Xu, J., Two-stage co-evaporated CuSbS2 thin films for solar cells. Journal of Alloys and Compounds 2016, 680, 182190.

64. Septina, W.; Ikeda, S.; Iga, Y.; Harada, T.; Matsumura, M., Thin film solar cell based on CuSbS2 absorber fabricated from an electrochemically deposited metal stack. Thin Solid Films 2014, 550, 700-704.

65. Liu, Z.; Huang, J.; Han, J.; Hong, T.; Zhang, J.; Liu, Z., $\mathrm{CuSbS} 2$ : a promising semiconductor photo-absorber material for quantum dot sensitized solar cells. Physical Chemistry Chemical Physics 2016, 18, (25), 16615-16620.

66. Choi, Y. C.; Yeom, E. J.; Ahn, T. K.; Seok, S. I., CuSbS2 -sensitized inorganic-organic heterojunction solar cells fabricated using a metal-thiourea complex solution. Angewandte Chemie 2015, 54, (13), 4005-9.

67. Rath, T.; MacLachlan, A. J.; Brown, M. D.; Haque, S. A., Structural, optical and charge generation properties of chalcostibite and tetrahedrite copper antimony sulfide thin films prepared from metal xanthates. Journal of Materials Chemistry A 2015, 3, (47), 24155-24162.

68. Tian, Q.; Wang, G.; Zhao, W.; Chen, Y.; Yang, Y.; Huang, L.; Pan, D., Versatile and Low-Toxic Solution Approach to Binary, Ternary, and Quaternary Metal Sulfide Thin Films and Its Application in $\mathrm{Cu} 2 \mathrm{ZnSn}(\mathrm{S}, \mathrm{Se}) 4$ Solar Cells. Chemistry of Materials 2014, 26, (10), 3098-3103.

69. Xu, Y.; Ye, Q.; Chen, W.; Pan, X.; Hu, L.; Yang, S.; Hayat, T.; Alsaedi, A.; Zhu, J.; Dai, S., Solution-processed CuSbS2 solar cells based on metal-organic molecular solution precursors. Journal of Materials Science 2018, 53, (3), 2016-2025.

70. Macías, C.; Lugo, S.; Benítez, Á.; López, I.; Kharissov, B.; Vázquez, A.; Peña, Y., Thin film solar cell based on CuSbS2 absorber prepared by chemical bath deposition (CBD). Materials Research Bulletin 2017, 87, 161-166.

71. Wan, L.; Guo, X.; Fang, Y.; Mao, X.; Guo, H.; Xu, J.; Zhou, R., Spray pyrolysis deposited CuSbS2 absorber layers for thin-film solar cells. Journal of Materials Science: Materials in Electronics 2019, 30, (24), 21485-21494.

72. Chesman, A. S. R.; van Embden, J.; Della Gaspera, E.; Duffy, N. W.; Webster, N. A. S.; Jasieniak, J. J., Cu2ZnGeS4 Nanocrystals from Air-Stable Precursors for Sintered Thin Film Alloys. Chemistry of Materials 2014, 26, (19), 5482-5491.

73. Welch, A. W.; Baranowski, L. L.; Peng, H.; Hempel, H.; Eichberger, R.; Unold, T.; Lany, S.; Wolden, C.; Zakutayev, A., Trade-Offs in Thin Film Solar Cells with Layered Chalcostibite Photovoltaic Absorbers. Advanced Energy Materials 2017, 7, (11), 1601935.

74. $\quad$ Su, Z.; Tan, J. M. R.; Li, X.; Zeng, X.; Batabyal, S. K.; Wong, L. H., Cation Substitution of Solution-Processed Cu2ZnSnS4 Thin Film Solar Cell with over 9\% Efficiency. Advanced Energy Materials 2015, 5, (19), 1500682.

75. Mitzi, D. B.; Yuan, M.; Liu, W.; Kellock, A. J.; Chey, S. J.; Deline, V.; Schrott, A. G., A High-Efficiency SolutionDeposited Thin-Film Photovoltaic Device. Advanced Materials 2008, 20, (19), 3657-3662.

76. Zunger, A.; Zhang, S. B.; Wei, S. H. In Revisiting the defect physics in CuInSe $\{s u b 2\}$ and $C u G a S e\{s u b 2\}$, United States, 1997-12-31, 1997; Institute of Electrical and Electronics Engineers, Inc., Piscataway, NJ (United States): United States, 1997.
77. Coughlan, C.; Ibáñez, M.; Dobrozhan, O.; Singh, A.; Cabot, A.; Ryan, K. M., Compound Copper Chalcogenide Nanocrystals. Chemical Reviews 2017, 117, (9), 5865-6109.

78. $\quad$ Hollingsworth, N.; Roffey, A.; Islam, H.-U.; Mercy, M.; Roldan, A.; Bras, W.; Wolthers, M.; Catlow, C. R. A.; Sankar, G.; Hogarth, G.; de Leeuw, N. H., Active Nature of Primary Amines during Thermal Decomposition of Nickel Dithiocarbamates to Nickel Sulfide Nanoparticles. Chemistry of Materials 2014, 26, (21), 6281-6292.

79. Singhal, S.; Garg, A. N.; Chandra, K., Thermal decomposition of transition metal dithiocarbamates. Journal of Thermal Analysis and Calorimetry 2004, 78, (3), 941-952.

80. Guo, Q.; Ford, G. M.; Yang, W.-C.; Walker, B. C.; Stach, E. A.; Hillhouse, H. W.; Agrawal, R., Fabrication of 7.2\% Efficient CZTSSe Solar Cells Using CZTS Nanocrystals. Journal of the American Chemical Society 2010, 132, (49), 17384-17386.

81. Dufton, J. T. R.; Walsh, A.; Panchmatia, P. M.; Peter, L. M.; Colombara, D.; Islam, M. S., Structural and electronic properties of $\mathrm{CuSbS} 2$ and $\mathrm{CuBiS} 2$ : potential absorber materials for thin-film solar cells. Physical Chemistry Chemical Physics 2012, 14, (20), 7229-7233.

82. Riha, S. C.; Koegel, A. A.; Emery, J. D.; Pellin, M. J.; Martinson, A. B. F., Low-Temperature Atomic Layer Deposition of CuSbS2 for Thin-Film Photovoltaics. ACS Applied Materials \& Interfaces 2017, 9, (5), 4667-4673.

83. Kim, J.; Hiroi, H.; Todorov, T. K.; Gunawan, O.; Kuwahara, M.; Gokmen, T.; Nair, D.; Hopstaken, M.; Shin, B.; Lee, Y. S.; Wang, W.; Sugimoto, H.; Mitzi, D. B., High Efficiency $\mathrm{Cu} 2 \mathrm{ZnSn}(\mathrm{S}, \mathrm{Se}) 4$ Solar Cells by Applying a Double In2S3/CdS Emitter. Advanced Materials 2014, 26, (44), 7427-7431.

84. Theresa John, T.; Mathew, M.; Sudha Kartha, C.; Vijayakumar, K. P.; Abe, T.; Kashiwaba, Y., CuInS2/In2S3 thin film solar cell using spray pyrolysis technique having 9.5\% efficiency. Solar Energy Materials and Solar Cells 2005, 89, (1), 27-36.

85. Yu, F.; Zhao, W.; Liu, S., A straightforward chemical approach for excellent In2S3 electron transport layer for highefficiency perovskite solar cells. RSC Advances 2019, 9, (2), 884890.

86. Mughal, M. A.; Engelken, R.; Sharma, R., Progress in indium (III) sulfide (In2S3) buffer layer deposition techniques for CIS, CIGS, and CdTe-based thin film solar cells. Solar Energy 2015, 120, 131-146.

87. Zuo, Y.; Chen, J.; Yang, H.; Zhang, M.; Wang, Y.; He, G.; Sun, Z., Facile synthesis of $\mathrm{TiO} 2 / \mathrm{In} 2 \mathrm{~S} 3 / \mathrm{CdS}$ ternary porous heterostructure arrays with enhanced photoelectrochemical and visible-light photocatalytic properties. Journal of Materials Chemistry C 2019, 7, (29), 9065-9074.

88. Nakada, T.; Kunioka, A., Direct evidence of Cd diffusion into $\mathrm{Cu}(\mathrm{In}, \mathrm{Ga}) \mathrm{Se} 2$ thin films during chemical-bath deposition process of CdS films. Applied Physics Letters 1999, 74, (17), 24442446.

89. Bhide, V. G.; Salkalachen, S.; Rastog, A. C.; Rao, C. N. R.; Hegde, M. S., Depth profile composition studies of thin film CdS:Cu2S solar cells using XPS and AES. Journal of Physics D: Applied Physics 1981, 14, (9), 1647-1656.

90. Snaith, H. J., The perils of solar cell efficiency measurements. Nature Photonics 2012, 6, (6), 337-340. 


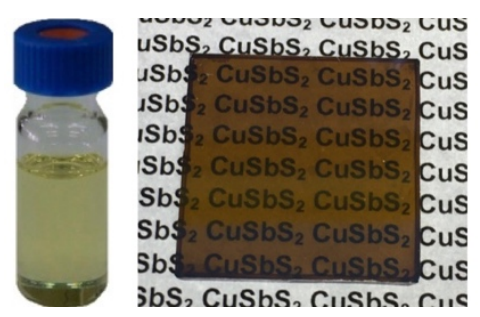

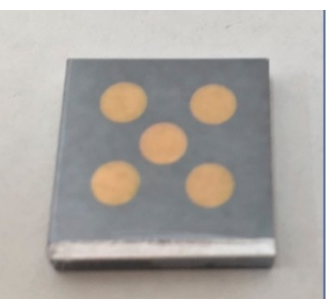

